\title{
The potential for biodiversity offsetting to fund effective invasive species control
}

\author{
David A. Norton* and Bruce Warburton $†$ \\ ${ }^{*}$ School of Forestry, University of Canterbury, Private Bag 4800, Christchurch 8140, New Zealand, email david.norton@canterbury. \\ ac.nz \\ †Landcare Research, P.O. Box 69040, Lincoln, 7640, New Zealand
}

\begin{abstract}
Compensating for biodiversity losses in 1 location by conserving or restoring biodiversity elsewhere (i.e., biodiversity offsetting) is being used increasingly to compensate for biodiversity losses resulting from development. We considered whether a form of biodiversity offsetting, enhancement offsetting (i.e., enhancing the quality of degraded natural habitats through intensive ecological management), can realistically secure additional funding to control biological invaders at a scale and duration that results in enhanced biodiversity outcomes. We suggest that biodiversity offsetting has the potential to enhance biodiversity values through funding of invasive species control, but it needs to meet 7 key conditions: be technically possible to reduce invasive species to levels that enhance native biodiversity; be affordable; be sufficiently large to compensate for the impact; be adaptable to accommodate new strategic and tactical developments while not compromising biodiversity outcomes; acknowledge uncertainties associated with managing pests; be based on an explicit risk assessment that identifies the cost of not achieving target outcomes; and include financial mechanisms to provide for in-perpetuity funding. The challenge then for conservation practitioners, advocates, and policy makers is to develop frameworks that allow for durable and effective partnerships with developers to realize the full potential of enhancement offsets, which will require a shift away from traditional preservation-focused approaches to biodiversity management.
\end{abstract}

Keywords: adaptive management, biodiversity offsetting, environmental compensation, invasive species, pest control

El Potencial de la Compensación de la Biodiversidad para Financiar Controles Efectivos de Especies Invasoras

Resumen: El compensar las pérdidas de la biodiversidad en una localidad al conservar o restaurar la biodiversidad en otra ( $p$. ej.: compensación de la biodiversidad), se está usando cada vez más para compensar las pérdidas de biodiversidad resultantes del desarrollo. Consideramos si una forma de compensación, el mejoramiento de compensaciones ( $p$. ej.: mejorar la calidad de los hábitats naturales degradados a través de manejo ecológico intensivo), puede asegurar realísticamente un financiamiento adicional para controlar invasores biológicos en una escala y duración que termine en resultados de biodiversidad mejorados. Sugerimos que la compensación de la biodiversidad tiene el potencial de mejorar los valores de la biodiversidad a través del financiamiento del control de especies invasoras, pero necesita cumplir siete condiciones clave: que la reducción de especies invasoras a niveles que mejoren la biodiversidad nativa sea técnicamente posible, que sea costeable, que sea lo suficientemente grande como para compensar el impacto, que sea adaptable para acomodar desarrollos estratégicos y tácticos nuevos y a su vez no comprometa los resultados de la biodiversidad, que reconozca incertidumbres asociadas con el manejo de plagas, que se base en una evaluación de riesgo específica que identifique los costos de no alcanzar los resultados objetivo, que incluya mecanismos financieros para proporcionar financiamiento a perpetuidad. Entonces el reto para los practicantes de la conservación, defensores y quienes hacen las políticas es desarrollar marcos de trabajo que permitan asociaciones efectivas con los desarrolladores para conocer el potencial total de las compensaciones 
de mejoras, lo que requiere un cambio al alejarse de las estrategias tradicionales enfocadas en la preservación bacia el manejo de la biodiversidad.

Palabras Clave: compensación ambiental, compensación de la biodiversidad, control de plagas, especies invasoras, manejo adaptativo

\section{Introduction}

Habitat loss is widely regarded as the biggest threat to endemic biodiversity (MEA 2005), and it results in substantial and ongoing species loss (Butchart et al. 2010; Pereira et al. 2010). Thus, preventing habitat loss forms the major focus of conservation policy and advocacy worldwide. Habitat loss is not, however, the only factor threatening endemic biodiversity, and even where natural ecosystems have been retained and included within protected natural areas, habitat quality can still be affected by other factors, including biological invasions (Fahrig 2003; MEA 2005).

Globally, biological invaders drive habitat loss by displacing native species and negatively affect the quality of the remaining habitat (e.g., through competition, predation, herbivory, and alteration of nutrient cycling and successional processes) (Simberloff et al. 2012). While the fundamental changes in community composition and structure resulting from invasive species are best documented on islands (Fritts \& Rodda 1998; Boyer 2008), they occur across all land masses and ecosystemsterrestrial, freshwater, and marine (Dextrase \& Mandrak 2006; Molnar et al. 2008; Eviner et al. 2010). These impacts are likely to increase (MEA 2005) as climate change provides new habitats for invasive species (Tylianakis et al. 2008; Bradley et al. 2010) and as global trade barriers break down resulting in the increased ability of organisms to invade new areas (Hume 2009).

While the impact of habitat loss is usually catastrophic for native biodiversity, it is possible with appropriate political, economic, and social intervention to prevent or reduce this, as evidenced by half of the world's 821 terrestrial ecoregions having $10 \%$ or more protected area coverage (Jenkins \& Joppa 2009). It is feasible to eradicate some biological invaders from some locations, especially islands (Howald et al. 2007) or areas where incursions are localized and recent (Gosling \& Baker 1989). However, eradication is currently unrealistic (at any effective scale) for most established invasive species. While many introduced species have a relatively benign impact on the resident biota, many invasive species have catastrophic impacts (Simberloff \& Rejmanek 2011). Ongoing management (at appropriate scales and frequencies) of these invasive species, even in permanently protected ecosystems, is essential if native biodiversity is to be sustained (Norton 2009a; PCE 2011).

Biological invasions and habitat loss are strongly interdependent (Didham et al. 2007); the number and abundance of invasive species is greater in landscapes with large amounts of habitat loss. However, even in landscapes with little habitat loss and where most native habitat is protected, biological invasions still occur (Wiser et al. 1998; White et al. 2008). Herein lies a major challenge for conservation biology: because the impacts of invasive species are ongoing and can occur in relatively unmodified, well-buffered, and legally protected areas such as national parks and reserves, their management places ongoing demands on scarce conservation resources. There are few examples of effective methods (e.g., biocontrol agents) for eradicating invasive species, and for most established invasive species in most places, there are no realistic options for doing this for the foreseeable future. Active and ongoing control of these established invasive species is therefore the only possible approach for sustaining native biodiversity. Unfortunately, in most parts of the world, there is insufficient funding allocated to sustain native biodiversity, as evidenced by ongoing species declines (e.g., Butchart et al. 2010).

We considered whether biodiversity offsetting, undertaken to compensate for adverse effects of a development project on biodiversity (BBOP 2012), is a realistic tool for securing additional funding to provide for the control of biological invaders at a scale and duration that can result in enhanced biodiversity outcomes. We reviewed the application of biodiversity offsetting, highlighting key factors that must be considered when using offsetting to achieve conservation outcomes. We considered a biological invasions case in New Zealand for which biodiversity offsetting has the potential to increase funding for the control of invasive species. Finally, we considered issues that need to be addressed to achieve large-scale and sustainable control of non-native invasive species through biodiversity offsets.

\section{Biodiversity Offsetting}

Society's demand for resources (food, energy, fiber, minerals, and space) often negatively affects biodiversity, especially through habitat loss. One tool to compensate for this loss is biodiversity offsetting, a trade-off between economic development and environmental protection (Morrison-Saunders \& Pope 2013) that seeks ecological compensation by achieving positive biodiversity conservation outcomes elsewhere (Norton 2009b; Gardner et al. 2013). In many countries, biodiversity offsets are a common legal requirement for development projects that impact biodiversity. Biodiversity offsetting is essentially a 


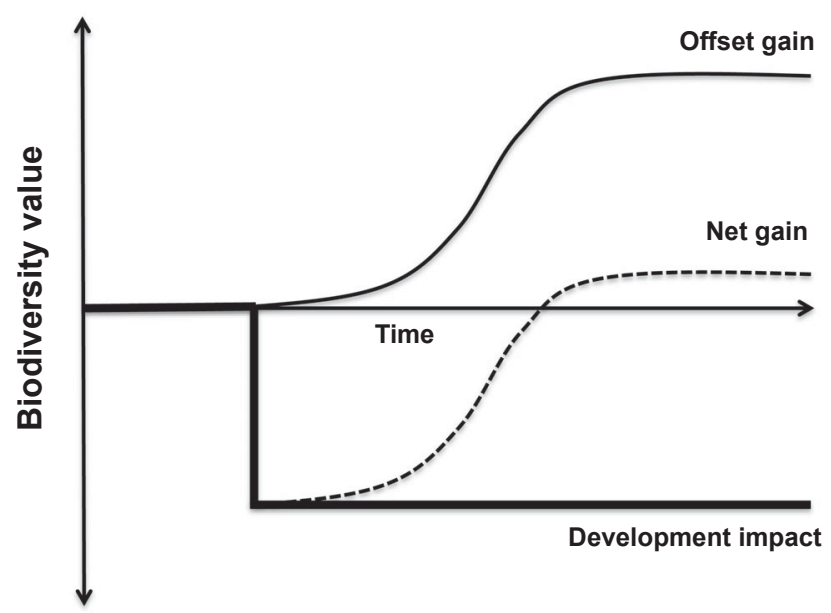

Figure 1. Biodiversity loss at impact site (thick line) versus biodiversity gain through an enbancement offset such as invasive species control at an offset site that is degraded at the start of enbancement management (thin line). The dashed line indicates net gain after taking into account the development impact. Because the biodiversity gain per unit area through invasive species control is usually less than the biodiversity loss due to development impact and because of the time taken to achieve the biodiversity gain, the offset area will almost always be substantially larger than the impact area.

framework and systematic analytical method for assessing the trade-off in biodiversity values between development and compensation sites and ensuring that the agreed upon compensatory work is implemented, monitored, and enforced.

A key prerequisite for biodiversity offsetting is the concept of "additionality" (McKenny \& Kiesecker 2010; BBOP 2012); this requires the offset to result in biodiversity gains that would not have otherwise occurred. Most biodiversity offsets have focused on either permanently protecting areas that are susceptible to future development (averted-loss offset) or enhancing the quality of degraded natural habitats through intensive ecological management (enhancement offset). This latter approach might involve restoration plantings, habitat manipulations, or the sustained control of invasive species resulting in a net gain in overall biodiversity values (Fig. 1). Enhancement offsets involving invasive species control are likely to be most effective in jurisdictions that already have reasonably comprehensive protected natural area systems or regulations that limit habitat loss, where established invaders continue to degrade native biodiversity, or where new invaders are encroaching.

Implementing biodiversity offsets as a tool to generate funding for conservation initiatives requires (Moilanen et al. 2009; Gardner et al. 2013; Pilgrim et al. 2013) ensuring that habitat loss associated with the agreed development impact neither exceeds an agreed level of degradation nor results in a species or ecosystem becoming more endangered; ensuring the biodiversity exchange between the loss of biodiversity at one site and the gain in biodiversity at another site is fair and quantification of biodiversity is meaningful; and providing guarantees that the offset will occur, result in measurable biodiversity gains, and be sustained until at least biodiversity goals have been achieved at the affected site. This last point is particularly important from an invasive species perspective and could include guarantees that a species will not reinvade if eradicated or that invasive species control can be sustained so as to maintain target biodiversity values.

One of the greatest challenges with enhancement offsets involving invasive species control is that any cessation of control will likely result in reinvasion and the subsequent loss of target biodiversity values (Norton 2009a). This is particularly important where the habitat loss associated with the development is absolute and cannot be reversed (e.g., an open-cut mine). Providing a guarantee of in-perpetuity management is also difficult because it is not possible to predict future regulatory or economic conditions. Notwithstanding this, an approach that has merit is the establishment of enduring or nonwasting endowment funds (i.e., funds that generate enough interest each year to cover the costs of annual management) (Teresa 2008) or similar financial instruments that provide guarantees of ongoing funding (Mandel et al. 2010).

\section{Vertebrate Invasions in New Zealand}

A good example of where enhancement offsets have the potential to produce substantial gains for biodiversity conservation is the control of invasive vertebrate pests in New Zealand. While invasive plants, invertebrates, fungi, and diseases also have impacts, it is a suite of invasive mammals that have had the greatest long-term effects on New Zealand's biodiversity-through the extinction of endemic vertebrates (mainly birds) and the decline of other species (reptiles, amphibians, invertebrates, and vascular plants) (Allen \& Lee 2006). The magnitude of these changes is difficult to appreciate when one-third of New Zealand is still covered by native vegetation, but dramatic changes have occurred in the 750 years since human settlement (Worthy \& Holdaway 2002).

New Zealand's avifauna continues to decline; many species are being sustained in relict, intensively managed populations (Robertson et al. 2007). Of 34 forest-bird taxa recorded from 1979 to 2004,15 (44\%) had declined (Innes et al. 2010; Table 1) in distribution and abundance. These declines were driven primarily by invasive predators and omnivores (Table 2). The substantial reduction 
Table 1. New Zealand threat classification and 1979-2004 distribution change for New Zealand forest birds, excluding species not recorded in either the 1969-1979 or 1999-2004 bird census.*

\begin{tabular}{lccc}
\hline & \multicolumn{3}{c}{ Distribution change (1979-2004) } \\
\cline { 2 - 4 } Threat category & Decrease & No change & Increase \\
\hline Threatened & 7 & 4 & 0 \\
At risk & 5 & 2 & 0 \\
Not threatened & 3 & 9 & 4 \\
\hline
\end{tabular}

* After Innes et al. (2010), except threat classification data are from Miskelly et al. (2008).

in density of native frugivorous and nectar-feeding birds has resulted in their functional extinction with respect to pollination and seed dispersal for some plant species (Anderson et al. 2011).

Similarly, herbivores (Table 2) occupy a range of habitats. Deer, primarily red deer (Cervus elaphus), have significantly modified the composition and structure of forest understories (Holloway 1950; Veblen \& Stewart 1982) and alpine grasslands (Rose \& Platt 1987) and adversely affected populations of most groups of litterdwelling mesofauna and macrofauna (Wardle et al. 2001).

Except on offshore islands or within fenced sanctuaries (Bellingham et al. 2010; Burns et al. 2012), the only option available to conservation managers is sustained control of invasive mammals to levels that allow key native biodiversity to persist (Saunders \& Norton 2001). Experience suggests that reducing the abundance of invaders will enhance biodiversity (Innes et al. 1999; Tanentzap et al. 2009). However, because of the high costs involved, most of New Zealand's remaining natural ecosystems are not subject to invasive species management; as a result, native biodiversity continues to decline (Green \& Clarkson 2006). For example, only $12 \%$ of the 8.5 million ha administered by the Department of Conservation receives sustained possum control (Departmental annual report 2012); sustained control of other species (ship rats, stoats, ferrets, and feral cats) is applied to a subset of this area. In effect, $88 \%$ of New Zealand's public conservation lands receive no sustained animal pest control (hereafter pest control is control of non-native invasive animals).

\section{Effectiveness of Pest Control for Biodiversity Enhancement}

To be effective, pest control programs must have a defined control target that pest abundance must be reduced to or below to obtain the desired level of biodiversity protection; an objective and defendable method for assessing control effectiveness and biodiversity outcomes; effective control tools for reducing pest abundance; and the necessary legislative and regulatory support (Warburton \& Norton 2009). Additionally, the control effort must be sustainable in perpetuity or until an alternative solution is found (Norton 2009a).

The major constraint on how much pest control can be carried out is cost, and this depends on the target pest species (affecting choice of method and frequency of control), the area treated (affecting contribution of immigration to population recovery), the pest reduction required to achieve the desired biodiversity response, and the up-front cost of establishing pest control infrastructure and baseline monitoring. Different pest species have different population growth rates (Southward et al. 1974), and species that have high growth rates (e.g., rodents) require more frequent control than species with low growth rates (e.g., ungulates). Furthermore, populations of native biodiversity will only recover when the abundance of a pest is reduced to or below a level at which these no longer constrain the recovery of the affected species (Choquenot \& Parkes 2001); for some native biodiversity, this level is very low and therefore expensive to achieve and maintain (Nugent et al. 2001).

Reduction of invasive species often results in predictable and desirable outcomes for biodiversity (Urlich \& Brady 2005; O’Donnell \& Hoare 2012). However, not all successful reductions of invasive species result in the expected recovery of the affected species or ecosystem. For example, in some situations, the effects of red deer may not be reversible (Coomes et al. 2003; St John et al. 2012). This occurs due to changes in ecosystem processes brought about by deer switching their diet to less palatable species, resulting in ongoing browse of palatable species even at low deer densities; increases in abundance of plant species not eaten by deer excluding reestablishment of palatable species; local extinction

Table 2. Non-native invasive animals that have affected New Zealand grassland and forest ecosystems since human arrival 750 years ago (Allen \& Lee 2006).

\begin{tabular}{|c|c|c|}
\hline Predators & Omnivores & Herbivores \\
\hline Stoats (Mustela erminea) & Ship rats (Rattus rattus) & $\begin{array}{l}\text { Deer (Cervus spp., Dama dama, Odocoileus } \\
\quad \text { virginianus) }\end{array}$ \\
\hline \multirow{4}{*}{$\begin{array}{l}\text { Feral cats (Felis catus) } \\
\text { Ferrets (Mustela putorius furo) }\end{array}$} & Possums (Trichosurus vulpecula) & Wallabies (Macropus spp.) \\
\hline & & Goats (Capra bircus) \\
\hline & Mice (Mus musculus) & $\begin{array}{l}\text { Rabbits (Oryctolagus cuniculus) and hares (Lepus } \\
\text { europaeus) }\end{array}$ \\
\hline & Pigs (Sus scrofa domesticus) & $\begin{array}{l}\text { Himalayan tahr (Hemitragus jemlabicus) and chamois } \\
\text { (Rupicapra rupicapra) }\end{array}$ \\
\hline
\end{tabular}


of seed sources; and the deer's fundamental alteration of successional pathways. Similarly, unexpected consequences can occur when small mammals are controlled. For example, Ruscoe et al. (2011) found that although the abundance of both brushtail possums (Tricbosurus vulpecula) and ship rats (Rattus rattus) in New Zealand forests can be significantly reduced by aerial application of poison baits, the high rate of increase of ship rats enables them to recover more rapidly and reach higher levels than before control because of the removal of competition from possums.

Consequently, to enhance biodiversity by applying cost-effective pest control and to sustain that enhancement long term, not only do strategic (i.e., spatial and temporal application) and tactical (i.e., method selection and application) considerations need to be addressed (Braysher 1993), but the possibility of unexpected outcomes must also be acknowledged and mitigated. Thus, pest control for biodiversity offsetting requires a good understanding of the biodiversity to be enhanced in the offset area, critical threats to this biodiversity, the target reduction in pest abundance required, the frequency and area over which control needs to be applied, and possible adverse interspecific interactions. Each will influence the cost of control, and this cost must be known if legitimate biodiversity offsetting is to be achieved through pest control actions. Due to these issues, the costs of pest control vary greatly. For example, in New Zealand, the cost (U.S. dollars per hectare per year) to maintain multiple species (e.g., possums, ship rats, and stoats) at low densities has been estimated at from \$38 to \$115 (Clapperton \& Day 2001), although more recent unpublished estimates suggest stoat control (lines of kill traps) costs approximately $\$ 5$, and targeting ship rats, stoats, and possums (3-4 yearly aerial applications of poison baits) costs \$4-\$8. Controlling ship rats in forest areas costs about $\$ 17$ (applying poison baits in bait stations when rodent irruptions are predicted [i.e., when production of mast is high]). In contrast, fenced sanctuaries (i.e., predator-proof fences potentially excluding all vertebrate pests except birds) cost from $\$ 162$ to $\$ 3400$ (Vessey et al. 2008).

A major challenge in implementing pest-control-based enhancement offsets is that control strategies and tactics are rapidly evolving. New methods are associated with ongoing uncertainties, for example, how to develop effective techniques for different ecosystem types, predict when to undertake different components of the control program, identify an efficient mix of control techniques (trapping and poisoning), and determine how long animal pest numbers will be suppressed following each control operation (O'Donnell 2010). Such uncertainties are a reality of management (Keith et al. 2011) and should not be an excuse for inaction. Instead, it is essential that initiatives to address biodiversity decline, including enhancement offsets, continue and that such programs be established within an adaptive management framework to ensure that the learning leads to more effective pest control programs (Parkes et al. 2006; Warburton \& Norton 2009). The importance of a strong link between goals and outcome monitoring in an adaptive management cycle is fundamental to pest management (Clayton \& Cowan 2010) and should be a core part of all enhancement offset programs.

While the principle of no net loss in applying biodiversity offsets is widely accepted, there is an increasing emphasis on aiming for a net biodiversity gain (BBOP 2012; Gardner et al. 2013). Where biodiversity decline through invasive species impacts are so marked, as in New Zealand, accepting a no-net-loss outcome is, in fact, normalizing the degraded state under benign-neglect management. Therefore, adoption of a net-positive-gain approach to biodiversity offsetting is essential if we are to make real progress in enhancing biodiversity. Walker et al. (2009) note, however, that developers have an imperative to minimize development costs including the costs of offsets, so the challenge for those advocating for improved biodiversity outcomes is to incentivize offsets so that developers will aim for clear net-gain outcomes rather than having to comply with strict no-net-loss goals. To achieve acceptance of net positive gain in biodiversity, 2 things need to occur. First, there needs to be a positive value proposition, so developers know that contributing funding is a good investment. Second, the pest control industry needs to reduce control costs as much as possible, so developers know that maximum benefits are being achieved for each dollar spent. Although offsets might be imposed on businesses through various legal requirements and when imposed will be met at least cost to the business, we suggest that there needs to be a change to proactive engagement by businesses in offsetting. Before this can happen, businesses need to know what the value proposition is for them (i.e., what premiums consumers might be willing to pay for biodiversity offsets). Additionally, what constitutes net positive gain (i.e., how large the offset-to-impact ratio should be) is still a matter of debate, but it is clear that with greater efficiencies in the implementation of invasive species control, there are opportunities for higher offset-to-impact ratios than have been the case in the past.

\section{Implementing Pest Control in Biodiversity Offsets}

Biodiversity offsetting based on enhancing biodiversity values through invasive species control has the potential to fund management above and beyond what is currently possible. It is likely to be applicable in a range of situations where invasive species have resulted in the degradation of native land cover. However, the implementation of such offsets will depend on meeting the following key conditions: that it be technically possible 
to reduce the abundance of invasive species to levels that result in meaningful positive responses in native biodiversity; that achieving a positive response in native biodiversity over a sufficiently large area that compensates for any planned adverse impacts is affordable and provides a positive value proposition to the company paying; that the area used for offsetting be sufficiently large to offset the impact area where biodiversity losses will be absolute (because enhancement offsets focus on habitats that are already dominated by native species, albeit in a degraded state); that enhancement offsets based on invasive species control be adaptable to accommodate new strategic and tactical developments in pest control while not compromising biodiversity outcomes; that offset programs acknowledge the uncertainty associated with managing pests and be developed within an adaptive management framework as a way of managing the risks associated with this uncertainty; that offset programs have an explicit risk assessment that identifies the cost of not achieving target outcomes and the actions that penalize nonperformance (i.e., the cost of failure needs to fall on the developer, not the community); and that the offset include financial mechanisms to provide for in-perpetuity funding (because any cessation of invasive species management will result in a loss of the values that the offset seeks to enhance and sustain).

When these conditions are met, enhancement offsetting has potential as a source of funding for biodiversity conservation. The challenge for conservation practitioners, advocates, and policy makers is to develop frameworks that allow for durable and effective partnerships with developers to realize these opportunities (Craig et al. 2013). We believe that offsets will work best when implemented through a partnership, but we recognize that there is also a need for a regulatory framework to underpin this. Development of a partnership approach will require a shift away from more traditional preservation-focused approaches to conservation management.

\section{Acknowledgments}

We thank P. Bellingham, B. Clarkson, R. Didham, C. Keye, and $\mathrm{J}$. Tylianakis for comments on an earlier draft, J. Parkes, G. Ussher, and R. Simcock for comments on the current version, and C. Bezar for editing.

\section{Literature Cited}

Allen, R. B., and W. R. Lee, editors. 2006. Biological invasions in New Zealand. Springer, Berlin.

Anderson, S. H., D, Kelly, J. J. Ladley, S. Molloy, and J. Terry. 2011. Cascading effects of bird functional extinction reduce pollination and plant density. Science 25:1068-1071.

BBOP (Business and Biodiversity Offsets Programme). 2012. Standard on biodiversity offsets. BBOP, Washington, D.C. Avail- able from http://bbop.forest-trends.org/guidelines/Standard.pdf (accessed April 2014).

Bellingham, P. J., D. R. Towns, E. K. Cameron, J. J. Davis, D. A. Wardle, J. M. Wilmshurst, and C. P. H. Mulder. 2010. New Zealand island restoration: seabirds, predators, and the importance of history. New Zealand Journal of Ecology 34:115-136.

Boyer, A. G. 2008. Extinction patterns in the avifauna of the Hawaiian Islands. Diversity and Distributions 14:509-517.

Bradley, B. A., D. M. Blumenthal, D. S. Wilcove, and L. H. Ziska. 2010 Predicting plant invasion in an era of global change. Trends in Ecology and Evolution 25:310-318.

Braysher, M. 1993. Managing vertebrate pests: principles and strategies. Commonwealth of Australia, Canberra, ACT.

Burns, B., J. Innes, and T. Day. 2012. The use and potential of pest-proof fencing for ecosystem restoration and fauna conservation in New Zealand. Pages 65-90 in M. J. Somers and M. W. Hayward, editors. Fencing for conservation. Springer, Berlin.

Butchart, S. H. M., et al. 2010. Global biodiversity: indicators of recent declines. Science 328:1164-1168.

Choquenot, D., and J. Parkes. 2001. Setting thresholds for pest control: How does pest density affect resource viability? Biological Conservation 99:29-46.

Clapperton, B. K., and T. D. Day. 2001. Cost-effectiveness of exclusion fencing for stoat and other pest control compared to conventional control. DOC Science Internal Series 14. Department of Conservation, Wellington.

Clayton, R., and P. Cowan. 2010. Management of animal and plant pests in New Zealand - patterns of control and monitoring by regional councils. Wildlife Research 37:360-371.

Coomes, D. A., R. B. Allen, D. M. Forsyth, and W G. Lee. 2003. Factors preventing the recovery of New Zealand forest following control of invasive deer. Conservation Biology 17:450-459.

Craig, J., H. Moller, D. Norton, D. Saunders, and M. Williams. 2013. Enhancing our heritage: Conservation for 21st century New Zealanders: ways forward from the Tahi Group of concerned scientists. Pacific Conservation Biology 19:256-269.

Dextrase, A. J., and N. E. Mandrak. 2006. Impacts of alien invasive species in freshwater fauna at risk in Canada. Biological Invasions 8:13-24.

Didham, R. K., J. M. Tylianakis, N. J. Gemmell, T. A. Rand, and R. M. Ewers. 2007. Interactive effects of habitat modification and species invasion on native species decline. Trends in Ecology \& Evolution 22:489-496.

Eviner, V. T., S. A. Hoskinson, and C. V. Hawkes. 2010. Ecosystem impacts of exotic plants can feed back to increase invasion in western US rangelands. Rangelands 32:21-31.

Fahrig, L. 2003. Effects of habitat fragmentation on biodiversity. Annual Review of Ecology and Systematics 34:487-515.

Fritts, T. H., and G. H. Rodda. 1998. The role of introduced species in the degradation of island ecosystems: a case history of Guam. Annual Review of Ecology and Systematics 29:113 -140 .

Gardner, T. A., et al. 2013. Biodiversity offsets and the challenge of achieving no net loss. Conservation Biology 27:1254-1264.

Gosling, L. M., and S. L. Baker. 1989. The eradication of muskrat and coypu from Britain. Biological Journal of the Linnean Society 38:3951.

Green, W., and B. Clarkson. 2006. Turning the tide? A review of the first five years of the New Zealand Biodiversity Strategy: the synthesis report. Department of Conservation, Wellington.

Holloway, J. T. 1950. Deer and the forests of western Southland. New Zealand Journal of Forestry 6:123-137.

Howald, G., et al. 2007. Invasive rodent eradication on islands. Conservation Biology 21:1258-1268.

Hume, P. E. 2009. Trade, transport and trouble: managing invasive species pathways in an era of globalization. Journal of Applied Ecology 46:10-18. 
Innes, J., D. Kelly, J. Overton, and C. Gillies. 2010. Predation and other factors currently limiting New Zealand forest birds. New Zealand Journal of Ecology 34:86-114.

Innes, J., R. Hay, I. Flux, P. Bradfeld, H. Speed, and P. Jansen. 1999. Successful recovery of North Island kokako Callaeas cinerea wilsoni populations, by adaptive management. Biological Conservation 87:201-214.

Jenkins, C. N., and L. Joppa. 2009. Expansion of the global terrestrial protected area system. Biological Conservation 14:21662174.

Keith, D. A., T. G. Martin, E. McDonald-Madden, and C. Walters. 2011. Uncertainty and adaptive management for biodiversity conservation. Biological Conservation 144:1175-1178.

Mandel, J. T., C. J. Donlan, and J. Armstrong. 2010. A derivative approach to endangered species conservation. Frontiers in Ecology and the Environment 8:44-49.

McKenny, B. A., and J. M. Kiesecker. 2010. Policy development for biodiversity offsets: a review of offset frameworks. Environmental Management 45:165-176.

MEA. 2005. Millennium ecosystem assessment, synthesis. Island Press, Washington, D.C.

Miskelly, C. M., J. E. Dowding, G. P. Elliott, R. A. Hitchmough, R. G. Powlesland, H. A. Robertson, P. M. Sagar, R. P. Scofield, and G. A. Taylor. 2008. Conservation status of New Zealand birds, 2008. Notornis 55:117-135.

Moilanen, A., A. J. A. van Teefelen, Y. Ben-Haim, and S. Ferrier. 2009. How much compensation is enough? A framework for incorporating uncertainty and time discounting when calculating offset ratios for impacted habitat. Restoration Ecology 17:470-478.

Molnar, J. L., R. L. Gamboa, C. Revenga, and M. D. Spalding. 2008. Assessing the global threat of invasive species to marine biodiversity. Frontiers in Ecology and Environment 6:485-492.

Morrison-Saunders, A., and J. Pope. 2013. Conceptualising and managing trade-offs in sustainability assessment. Environmental Impact Assessment Review 38:54-63.

Norton, D. A. 2009a. Species invasions and the limits to restoration: learning from the New Zealand experience. Science 325:569-571.

Norton, D. A. 2009b. Biodiversity offsets - two New Zealand case studies and an assessment framework. Environmental Management 43:698706.

Nugent, G., W. Fraser, and P. Sweetapple. 2001. Top down or bottom up? Comparing the impacts of introduced arboreal possums and 'terrestrial' ruminants on native forests in New Zealand. Biological Conservation 99:65-79.

O'Donnell, C. F. J. 2010. Statement of evidence before the Environment Court at Christchurch [Proposed Mokikinui hydro scheme appeal]. ENV-2010-CHC-115, 123, 124 and 135.

O'Donnell, C. F. J., and J. M. Hoare. 2012. Quantifying the benefits of long-term integrated pest control for forest bird populations in a New Zealand temperate rainforest. New Zealand Journal of Ecology 36:131-140.

Parkes, J. P., A. Robley, D. M. Forsyth, and D. Choquenot. 2006. Adaptive management experiments in vertebrate pest control in New Zealand and Australia. Wildlife Society Bulletin 34:229-236.

PCE (Parliamentary Commissioner for the Environment). 2011. Evaluating the use of 1080: Predators, poisons and silent forests. PCE, Wellington.

Pereira, H. M., et al. 2010. Scenarios for global biodiversity in the 21 st century. Science 330:1496-1501.

Pilgrim, J. D., et al. 2013. A process for assessing the offsetability of biodiversity impacts. Conservation Letters 6:376-385.
Robertson, C. J. R., P. Hyvönen, M. J. Fraser, and C. R. Pickard. 2007. Atlas of bird distribution in New Zealand 1999-2004. The Ornithological Society of New Zealand, Wellington.

Rose, A. B., and K. H. Platt. 1987. Recovery of northern Fiordland alpine grasslands after reduction in the deer population. New Zealand Journal of Ecology 10:23-33.

Ruscoe, W. A., et al. 2011. Unexpected consequences of control: competitive vs. predator release in a four-species assemblage of invasive mammals. Ecology Letters 14:1035-1042.

Saunders, A., and D. A. Norton. 2001. Ecological restoration of mainland islands in New Zealand. Biological Conservation 99:109-119.

Simberloff, D., et al. 2012. Impacts of biological invasions: what's what and the way forward. Trends in Ecology and Evolution 28: 58-66.

Simberloff, D., and M. Rejmanek, editors. 2011. Encyclopedia of biological invasions. University of California Press, Berkeley, California.

Southward, T. R. E., R. M. May, M. P. Hassell, and G. R. Conway. 1974. Ecological strategies and population parameters. The American Naturalist 108:791-804.

St John, M. G., P. J. Bellingham, L. R. Walker, K. H. Orwin, K. I. Bonner, I. A. Dickie, C. W. Morse, G. W. Yeates, and D. A. Wardle. 2012. Loss of dominant nitrogen-fixing shrub in primary succession: consequences for plant and below-ground communities. Journal of Ecology 100:1074-1084.

Tanentzap, A. J., L. E. Burrows, W. G. Lee, G. Nugent, J. Maxwell, and D. A. Coomes. 2009. Landscape-level vegetation recovery from herbivory: progress after four decades of intensive red deer control. Journal of Applied Ecology 46:1064-1072.

Teresa, S. 2008. Financial considerations. Pages 127-155 in N. Carroll, J. Fox and R. Bayon, editors. Conservation and biodiversity banking, Earthscan, London.

Tylianakis, J. M., R. K. Didham, J. Bascompte, and D. A. Wardle. 2008. Global change and species interactions in terrestrial ecosystems. Ecology Letters 11:1351-1363.

Urlich S. C., and P. J. Brady. 2005. Benefits of aerial 1080 possum control to tree fuchsia in the Tararua Range, Wellington. New Zealand Journal of Ecology 29:299-309.

Veblen, T. T., and G. H. Stewart. 1982. The effects of introduced wild animals on New Zealand forests. Annals of the Association of American Geographers 72:372-397.

Vessey, S. E., R. Cullen, and K. F. D. Hughey. 2008. State and notfor-profit delivery of species conservation. Cost utility analysis of multiple-species projects. New Zealand Agricultural and Resource Economics Society Conference, Nelson, New Zealand.

Walker, S., A. L. Brower, R. T. T. Stephens, and W. G. Lee. 2009. Why bartering biodiversity fails. Conservation Letters 2:149-157.

Warburton, B., and B. G. Norton. 2009. Towards a knowledge-based ethic for lethal control of nuisance wildlife. Journal of Wildlife Management 73:158-164.

Wardle, D. A., G. M. Barker, G. W. Yeates, K. I. Bonner, and A. Ghani. 2001. Introduced browsing mammals in New Zealand natural forests: aboveground and belowground consequences. Ecological Monographs 71:587-614.

White, P. C. L., A. E. S. Ford, M. N. Clout, R. M. Engeman, S. Roy, and G. Saunders. 2008. Alien invasive vertebrates in ecosystems: pattern, process and the social dimension. Wildlife Research 35:171-179.

Wiser, S. K., R. B. Allen, P. W. Clinton, and K. H. Platt. 1998. Community structure and forest invasion by an exotic herb over 23 years. Ecology 79:2071-2081.

Worthy, T. H., and R. N. Holdaway. 2002. The lost world of the moa. Canterbury University Press, Christchurch, New Zealand. 